\title{
Expansionary Yet Different: \\ Credit Supply and Real Effects of Negative Interest Rate Policy
}

\section{Online Appendix}

\author{
Margherita Bottero \\ Camelia Minoiu \\ Andrea Polo \\ Andrea F. Presbitero \\ José-Luis Peydró \\ Enrico Sette
}




\section{A.1 Additional Figures}

Figure A1: Net Interbank Position and Liquidity in December 2013 and March 2014

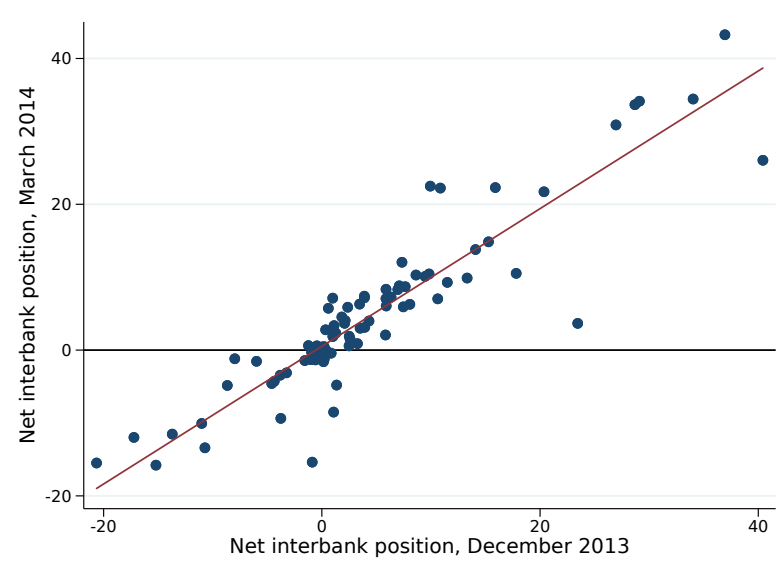

(a) Net interbank position

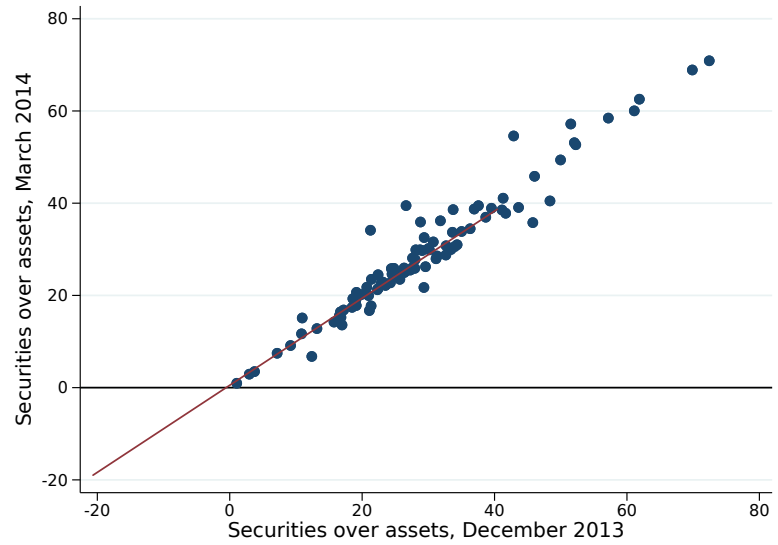

(b) Liquidity

Notes: The chart plots the correlation between the net interbank positions (calculated as the ratio of interbank loans minus interbank deposits with maturity up to one week, in percent of total assets) and liquidity (calculated as the ratio of securities over total assets, in percent) measured in December 2013 and March 2014. The variables are winsorized at the $1^{\text {st }}$ and $99^{\text {th }}$ percentiles. Source: Bank of Italy. 


\section{Figure A2: Net Interbank Position and Liquidity}

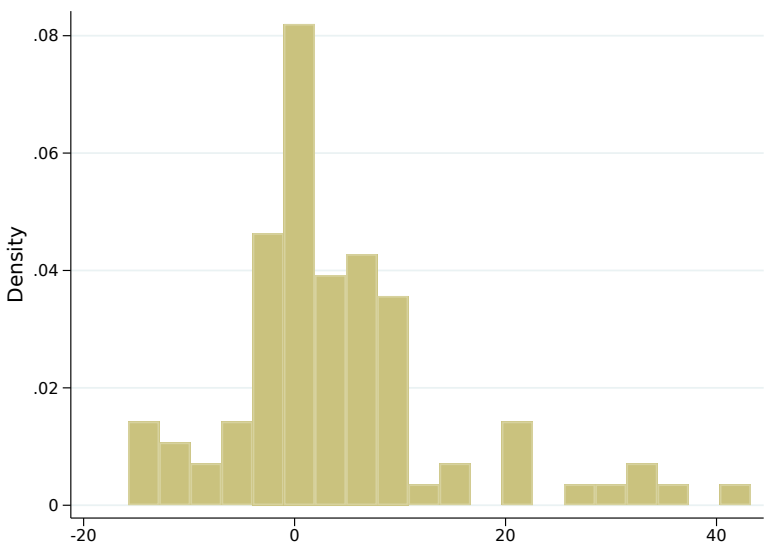

(a) Net interbank position

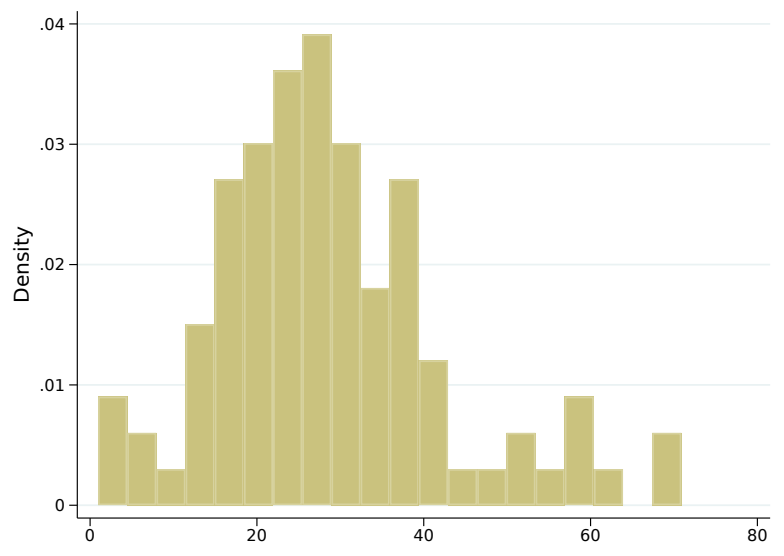

(b) Liquidity

Notes: The chart plots the distribution of: i) the net interbank position, measured as interbank loans minus interbank deposits with maturity of up to one week, in percent of total assets (panel a); and ii) liquidity, measured as securities in percent of total assets (panel b). Both variables are measured as of March 2014 and are winsorized at the $1^{\text {st }}$ and $99^{\text {th }}$ percentiles. The sample includes 95 banks. Source: Bank of Italy. 


\section{A.2 Additional Tables}

\section{Table A1: Negative Policy Rates and Bank Profitability}

Notes: The table shows OLS estimates of a bank-level cross sectional regression. The dependent variables are: i) the change in return on equity (column 1), and ii) the change in the net interest margin over the six months following the introduction of NIRP, June-December 2014. The net interbank position, defined as the ratio of interbank loans minus interbank deposits with maturity up to one week, over total assets; liquidity, defined as the ratio of securities over total assets; and retail deposits, computed as a share of total assets, are all measured as of end-March 2014. Bank control variables include: i) Size, defined as the logarithm of total assets; ii) Capital, defined as the ratio of TIER 1 capital over total assets; and iii) NPL, defined as non-performing loans scaled by total assets. Also the control variables are measured before the announcement of NIRP. Robust standard errors in parentheses. ${ }^{* * *} \mathrm{p}<0.01,{ }^{* *} \mathrm{p}<0.05,{ }^{*} \mathrm{p}<0.1$.

\begin{tabular}{|c|c|c|}
\hline & $\begin{array}{l}(1) \\
\Delta \mathrm{ROE}\end{array}$ & $\begin{array}{l}(2) \\
\Delta \text { NIM }\end{array}$ \\
\hline Interbank position & $\begin{array}{l}0.3909 \\
(7.1347)\end{array}$ & $\begin{array}{l}0.1345 \\
(0.1505)\end{array}$ \\
\hline Liquidity & $\begin{array}{l}0.7732 \\
(7.2762)\end{array}$ & $\begin{array}{l}0.1030 \\
(0.1248)\end{array}$ \\
\hline Retail deposits & $\begin{array}{l}3.1337 \\
(5.7906)\end{array}$ & $\begin{array}{l}-0.0496 \\
(0.0857)\end{array}$ \\
\hline Observations & 90 & 90 \\
\hline Bank controls & Yes & Yes \\
\hline$R^{2}$ & 0.1155 & 0.1490 \\
\hline
\end{tabular}




\section{Table A2: Negative Policy Rates and Fee Income on Bank Deposits}

Notes: The table shows OLS estimates of a bank-level cross sectional regression. The dependent variable is the change in banks' income from fees on bank deposits over the six months following the introduction of NIRP, June-December 2014 (data on income from fees is available bi-annually). Retail deposits are measured as a share of total assets, as of end-March 2014. Bank control variables include: i) Net interbank position, defined as the ratio of interbank loans minus interbank deposits with maturity up to one week, over total assets; ii) Liquidity, defined as the ratio of securities over total assets; iii) Size, defined as the logarithm of total assets; iv) Capital, defined as the ratio of TIER 1 capital over total assets; and v) NPL, defined as non-performing loans scaled by total assets. Also the control variables are measured before the announcement of NIRP. Data on income from fees are missing for 12 banks in our baseline sample. If we assume that these banks have no income from fees, results on the full sample of 95 banks do not change (e.g., the point estimates and significance level are almost identical). Robust standard errors in parentheses. ${ }^{* * *} \mathrm{p}<0.01,{ }^{* *} \mathrm{p}<0.05,{ }^{*} \mathrm{p}<0.1$.

(1)

(2)

Change in fee income from bank deposits

$\begin{array}{lll} & 0.0031^{* * *} & 0.0024^{* * *} \\ \end{array}$

$(0.0007) \quad(0.0007)$

\begin{tabular}{lll}
\hline Observations & 83 & 83 \\
Bank controls & No & Yes \\
$R^{2}$ & 0.2111 & 0.3886
\end{tabular}




\section{Table A3: Descriptive Statistics}

Notes: Panel A refers to bank-level variables. Net interbank position is measured as the ratio of interbank loans minus interbank deposits with maturity up to one week, over total assets. Liquidity is the ratio of securities over total assets. Size is defined as the logarithm of total assets. Capital is the ratio of TIER 1 capital over total assets. NPL is non-performing loans scaled by total assets. Retail deposits are measured as a share of total assets. TLTRO is the ratio of total loans to euro area non-financial corporations and households-excluding loans to households for house purchase-over total assets, as of April 2014. Secured Repo is the ratio of secured repo funding over total assets. Liabilities vis-a-vis non resident is the ratio of foreign funding (deposits from non-residents) over total assets. Securities issues is the ratio of bank-issued securities over total assets. Interbank deposits is the ratio of interbank deposits over total assets. Windfall gain is the sum of individual revaluation gains over all the securities in the marked-to-market portfolios around NIRP as a fraction of a bank's total equity. All these variables are measured as of March 2014. Income fees over assets refer to fees on bank deposits and it is measured as of June 2014. Panel B refers to loan-level variables. $\Delta$ Loan is measured as log difference between the average total exposure of a given firm with a given bank in the post-NIRP period (July-September 2014) and the correspondent average total exposure in the pre-NIRP period (March-May 2014). Net rates are the average loan rates charged by a given bank to a given firm on credit lines and credit facilities, and on term loans. Panel C refers to firm-level variables. $\Delta$ Loan is the loan growth at the firm-month level, calculated as log difference between the post- and the pre-NIRP period. Net investment is the growth rate of fixed assets between 2014 and 2013. Wage bill growth is the growth rate of the wage bill between 2014 and 2013.

\begin{tabular}{|c|c|c|c|c|}
\hline & Mean & St.Dev. & Median & Obs. \\
\hline \multicolumn{5}{|l|}{ Panel A: Bank-level variables } \\
\hline Net interbank position, March 2014 & 4.200 & 10.810 & 1.862 & 95 \\
\hline Liquidity, March 2014 & 28.670 & 13.950 & 25.940 & 95 \\
\hline Size & 7.667 & 2.310 & 7.598 & 95 \\
\hline Capital & 8.533 & 5.768 & 7.079 & 95 \\
\hline NPL & 4.348 & 3.555 & 3.868 & 95 \\
\hline Retail deposits, March 2014 & 45.260 & 16.120 & 44.650 & 95 \\
\hline TLTRO & 35.670 & 12.560 & 36.370 & 95 \\
\hline Secured Repo & 2.918 & 8.172 & 0.000 & 95 \\
\hline Liabilities vis-a-vis non-resident & 1.390 & 2.240 & 0.245 & 95 \\
\hline Securities issued & 14.520 & 10.200 & 14.560 & 95 \\
\hline Interbank deposits & 13.780 & 9.785 & 12.760 & 95 \\
\hline Windfall gain & 1.378 & 1.525 & 0.919 & 95 \\
\hline Income fees & 0.124 & 0.107 & 0.099 & 83 \\
\hline \multicolumn{5}{|l|}{ Panel B: Loan-level variables } \\
\hline$\Delta$ Loan & -2.137 & 20.435 & 0.000 & 495,942 \\
\hline Net rates, credit lines and overdraft facilities & 8.375 & 3.129 & 7.928 & 205,091 \\
\hline Net rates, term loans & 3.916 & 1.569 & 3.827 & 113,801 \\
\hline \multicolumn{5}{|l|}{ Panel C: Firm-level variables } \\
\hline$\Delta$ Loan & -1.693 & 20.380 & -0.899 & 141,390 \\
\hline Net investment & 11.463 & 77.175 & -2.564 & 134,248 \\
\hline Wage bill growth & -1.123 & 31.991 & 1.258 & 127,297 \\
\hline
\end{tabular}




\section{Table A4: Negative Policy Rates, Net Interbank Position, and Liquidity}

Notes: The table shows OLS estimates of a bank-level cross sectional regression. The dependent variable measures the change between March and September 2014 of banks': 1) net interbank position (column 1); 2) interbank loans with maturity up to one week over assets (column2); 3) interbank deposits with maturity up to one week over assets (column 3); and liquidity, measured as the ratio of securities over total assets (column 4). Net interbank position is measured as the ratio of interbank loans minus interbank deposits with maturity up to one week, over total assets, as of end-March 2014. Liquidity is the ratio of securities over total assets, as of March 2014. Bank control variables include: i) Size, defined as the logarithm of total assets; ii) Capital, defined as the ratio of TIER 1 capital over total assets; and iii) NPL, defined as non-performing loans scaled by total assets. These three variables are measured as of March 2014. Robust standard errors in parentheses. ${ }^{* * *} \mathrm{p}<0.01,{ }^{* *} \mathrm{p}<0.05,{ }^{*} \mathrm{p}<0.1$.

\begin{tabular}{lllll}
\hline & $\begin{array}{l}\Delta \text { net interbank po- } \\
\text { sition after NIRP } \\
(1)\end{array}$ & $\begin{array}{l}\Delta \text { interbank loans } \\
\text { after NIRP } \\
(2)\end{array}$ & $\begin{array}{l}\Delta \text { interbank de- } \\
\text { posits after NIRP } \\
(3)\end{array}$ & $\begin{array}{l}\Delta \text { liquidity after } \\
\text { NIRP } \\
(4)\end{array}$ \\
\cline { 2 - 5 } Net interbank position & $-0.2180^{* * *}$ & $-0.1644^{* *}$ & 0.0536 & 0.0530 \\
Liquidity & $(0.0851)$ & $(0.0741)$ & $\begin{array}{l}(0.0545) \\
(0.0501)\end{array}$ & $-0.1016^{* *}$ \\
& -0.0398 & -0.0080 & 0.0318 & $(0.0394)$ \\
\hline Observations & $(0.0407)$ & $(0.0369)$ & $(0.0214)$ & 95 \\
Bank controls & 95 & 95 & 95 & Yes \\
$R^{2}$ & Yes & Yes & Yes & 0.1509 \\
\hline
\end{tabular}




\section{Table A5: Net interbank position, Liquidity, and Bank Characteristics}

Notes: The table shows OLS estimates of a bank-level cross sectional regression. The dependent variable is, alternatively, the net interbank position (column 1) and liquidity (column 2). The net interbank position is measured as the ratio of interbank loans minus interbank deposits with maturity up to one week, over total assets, as of end-March 2014. Liquidity is the ratio of securities over total assets, as of March 2014. Bank control variables include: i) Size, defined as the logarithm of total assets; ii) Capital, defined as the ratio of TIER 1 capital over total assets; and iii) NPL, defined as non-performing loans scaled by total assets. These three variables are measured as of June 2014 . Robust standard errors in parentheses. ${ }^{* * *} \mathrm{p}<0.01,{ }^{* *} \mathrm{p}<0.05,{ }^{*} \mathrm{p}<0.1$.

\begin{tabular}{|c|c|c|}
\hline & $\begin{array}{l}\text { Net interbank position } \\
\text { (1) }\end{array}$ & $\begin{array}{l}\text { Liquidity } \\
\text { (2) }\end{array}$ \\
\hline Size & $\begin{array}{l}-2.2878^{* * *} \\
(0.4614)\end{array}$ & $\begin{array}{l}-0.3338 \\
(0.5773)\end{array}$ \\
\hline Capital & $\begin{array}{l}0.2630 \\
(0.2178)\end{array}$ & $\begin{array}{l}-0.8104^{* * * *} \\
(0.2526)\end{array}$ \\
\hline NPL & $\begin{array}{l}0.0725 \\
(0.3030)\end{array}$ & $\begin{array}{l}-1.8584^{* * * *} \\
(0.3580)\end{array}$ \\
\hline $\begin{array}{l}\text { Observations } \\
R^{2}\end{array}$ & $\begin{array}{l}95 \\
0.3340\end{array}$ & $\begin{array}{l}95 \\
0.2425\end{array}$ \\
\hline
\end{tabular}


Table A6: Balancing of Observable Firm Characteristics

Notes: The table report, for each variable, the average values computed by quartile of bank exposure to NIRP, considering the net interbank position (Panel A) or liquidity (Panel B). Net interbank position is measured as the ratio of interbank loans minus interbank deposits with maturity up to one week, over total assets. Liquidity is the ratio of securities over total assets. Firm size is the log of firm's assets; Zscore is the Altman Z-score (Altman, 1968) computed by CERVED; Equity/Debt is the ratio of the book value of equity to firm's debt; Profitability is the ratio of earnings before interest taxes, depreciation and amortization (EBITDA) to firm's assets. In parentheses we report the normalized differences (the difference between the quartile average and the average of the other three quartiles, normalized by the square root of the sum of the corresponding variances). According to the rule of thumb proposed by Imbens and Wooldridge (2009), two variables have "similar" means when the normalized difference is less than 0.25 .

\begin{tabular}{|c|c|c|c|c|}
\hline & $1^{\text {st }}$ Quartile & $2^{\text {nd }}$ Quartile & $3^{\text {rd }}$ Quartile & $4^{\text {th }}$ Quartile \\
\hline & \multicolumn{4}{|c|}{ Panel A. Net interbank position } \\
\hline Firm size & $\begin{array}{l}7.639 \\
(0.004)\end{array}$ & $\begin{array}{l}7.721 \\
(0.071)\end{array}$ & $\begin{array}{l}7.547 \\
(-0.075)\end{array}$ & $\begin{array}{l}7.642 \\
(0.006)\end{array}$ \\
\hline Z-score & $\begin{array}{l}5.118 \\
(-0.048)\end{array}$ & $\begin{array}{l}5.188 \\
(0.001)\end{array}$ & $\begin{array}{l}5.142 \\
(-0.031)\end{array}$ & $\begin{array}{l}5.315 \\
(0.086)\end{array}$ \\
\hline Equity/Debt & $\begin{array}{l}0.528 \\
(0.053)\end{array}$ & $\begin{array}{l}0.487 \\
(-0.009)\end{array}$ & $\begin{array}{l}0.498 \\
(0.008)\end{array}$ & $\begin{array}{l}0.453 \\
(-0.060)\end{array}$ \\
\hline \multirow[t]{2}{*}{ Profitability } & $\begin{array}{l}5.959 \\
(0.005)\end{array}$ & $\begin{array}{l}5.726 \\
(-0.020)\end{array}$ & $\begin{array}{l}6.144 \\
(0.026)\end{array}$ & $\begin{array}{l}5.792 \\
(-0.013)\end{array}$ \\
\hline & \multicolumn{4}{|c|}{ Panel B. Liquidity } \\
\hline Firm size & $\begin{array}{l}7.602 \\
(0.021)\end{array}$ & $\begin{array}{l}7.681 \\
(0.064)\end{array}$ & $\begin{array}{l}7.568 \\
(0.070)\end{array}$ & $\begin{array}{l}7.723 \\
(0.057)\end{array}$ \\
\hline Z-score & $\begin{array}{l}5.375 \\
(0.102)\end{array}$ & $\begin{array}{l}5.113 \\
(0.081)\end{array}$ & $\begin{array}{l}5.256 \\
(0.060)\end{array}$ & $\begin{array}{l}5.346 \\
(0.086)\end{array}$ \\
\hline Equity/Debt & $\begin{array}{l}0.425 \\
(0.083)\end{array}$ & $\begin{array}{l}0.521 \\
(0.069)\end{array}$ & $\begin{array}{l}0.464 \\
(0.054)\end{array}$ & $\begin{array}{l}0.445 \\
(0.057)\end{array}$ \\
\hline Profitability & $\begin{array}{l}5.443 \\
(0.041)\end{array}$ & $\begin{array}{l}5.924 \\
(0.002)\end{array}$ & $\begin{array}{l}5.958 \\
(0.006)\end{array}$ & $\begin{array}{l}5.698 \\
(0.0190)\end{array}$ \\
\hline
\end{tabular}




\section{Table A7: Negative Policy Rates and Bank Credit Supply—Baseline regressions, all variables}

Notes: The table presents OLS estimates of model 1. The dependent variable is loan growth at the bank-firm-month level, calculated as $\log$ difference between the post- and the pre-NIRP period. The length of the pre- and post-NIRP periods ranges between 3 and six months, centered around June 2014, which is excluded from the sample. Net interbank position is measured by the ratio of interbank loans minus interbank deposits with maturity up to one week, over total assets, as of end-March 2014. Liquidity is the ratio of securities over total assets, as of March 2014. Size is defined as the logarithm of total assets. Capital is defined as the ratio of TIER 1 capital over total assets. NPL is defined as non-performing loans scaled by total assets. Retail deposits are measured as a share of total assets. All these variables are measured as of March 2014. TLTRO is the ratio of total loans to euro area non-financial corporations and households-excluding loans to households for house purchase- over total assets, as of April 2014. Standard errors, double clustered at the bank and firm level, are in parentheses. ${ }^{* * *} \mathrm{p}<0.01,{ }^{* *} \mathrm{p}<0.05,{ }^{*} \mathrm{p}<0.1$.

\begin{tabular}{|c|c|c|c|c|c|}
\hline Window: & \multicolumn{4}{|c|}{ \pm 3 month around June 2014} & (5) \\
\hline Net interbank position & $\begin{array}{l}0.1438^{* *} \\
(0.0610)\end{array}$ & & $\begin{array}{l}0.1283^{* *} \\
(0.0597)\end{array}$ & $\begin{array}{l}0.1249^{* *} \\
(0.0605)\end{array}$ & $\begin{array}{l}0.1232^{*} \\
(0.0631)\end{array}$ \\
\hline Liquidity & & $\begin{array}{l}0.0586^{* * *} \\
(0.0179)\end{array}$ & $\begin{array}{l}0.0551^{* * *} \\
(0.0179)\end{array}$ & $\begin{array}{l}0.0648^{* * *} \\
(0.0194)\end{array}$ & $\begin{array}{l}0.0625^{* * * *} \\
(0.0208)\end{array}$ \\
\hline Size & $\begin{array}{l}0.1446^{* *} \\
(0.0635)\end{array}$ & $\begin{array}{l}0.2300^{* * *} \\
(0.0611)\end{array}$ & $\begin{array}{l}0.2378^{* * *} \\
(0.0601)\end{array}$ & $\begin{array}{l}0.3391^{* * *} \\
(0.1163)\end{array}$ & $\begin{array}{l}0.3313^{* * *} \\
(0.1176)\end{array}$ \\
\hline Capital & $\begin{array}{l}-0.1749^{* *} \\
(0.0796)\end{array}$ & $\begin{array}{l}-0.0996^{*} \\
(0.0523)\end{array}$ & $\begin{array}{l}-0.1328^{* *} \\
(0.0542)\end{array}$ & $\begin{array}{l}-0.1477^{* *} \\
(0.0572)\end{array}$ & $\begin{array}{l}-0.1615^{* * *} \\
(0.0596)\end{array}$ \\
\hline NPL & $\begin{array}{l}-0.0889 \\
(0.0686)\end{array}$ & $\begin{array}{l}-0.0517 \\
(0.0628)\end{array}$ & $\begin{array}{l}-0.0604 \\
(0.0625)\end{array}$ & $\begin{array}{l}-0.0603 \\
(0.0630)\end{array}$ & $\begin{array}{l}-0.0467 \\
(0.0739)\end{array}$ \\
\hline $\begin{array}{l}\text { Retail deposits } \\
\text { TLTRO }\end{array}$ & & & & $\begin{array}{l}0.0174 \\
(0.0211)\end{array}$ & $\begin{array}{l}0.0243 \\
(0.0251) \\
-0.0141 \\
(0.0308)\end{array}$ \\
\hline Observations & 495942 & 495942 & 495942 & 495942 & 495942 \\
\hline Bank controls & Yes & Yes & Yes & Yes & Yes \\
\hline Firm FE & Yes & Yes & Yes & Yes & Yes \\
\hline$R^{2}$ & 0.3726 & 0.3727 & 0.3728 & 0.3728 & 0.3728 \\
\hline Window: & \multicolumn{5}{|c|}{ \pm 6 month around June 2014} \\
\hline Net interbank position & $\begin{array}{l}0.1972^{* *} \\
(0.0803)\end{array}$ & & $\begin{array}{l}0.1778^{* *} \\
(0.0771)\end{array}$ & $\begin{array}{l}0.1720^{* *} \\
(0.0773)\end{array}$ & $\begin{array}{l}0.1683^{* *} \\
(0.0800)\end{array}$ \\
\hline Liquidity & & $\begin{array}{l}0.0735^{* *} \\
(0.0296)\end{array}$ & $\begin{array}{l}0.0686^{* *} \\
(0.0288)\end{array}$ & $\begin{array}{l}0.0854^{* * *} \\
(0.0322)\end{array}$ & $\begin{array}{l}0.0803^{* *} \\
(0.0354)\end{array}$ \\
\hline Size & $\begin{array}{l}0.1562 \\
(0.1119)\end{array}$ & $\begin{array}{l}0.2617^{* *} \\
(0.1003)\end{array}$ & $\begin{array}{l}0.2725^{* * *} \\
(0.0989)\end{array}$ & $\begin{array}{l}0.4467^{* *} \\
(0.1767)\end{array}$ & $\begin{array}{l}0.4298^{* *} \\
(0.1803)\end{array}$ \\
\hline Capital & $\begin{array}{l}-0.1940 \\
(0.1234)\end{array}$ & $\begin{array}{l}-0.0952 \\
(0.0930)\end{array}$ & $\begin{array}{l}-0.1412 \\
(0.0982)\end{array}$ & $\begin{array}{l}-0.1668^{*} \\
(0.1002)\end{array}$ & $\begin{array}{l}-0.1964^{*} \\
(0.1040)\end{array}$ \\
\hline NPL & $\begin{array}{l}-0.0810 \\
(0.1202)\end{array}$ & $\begin{array}{l}-0.0334 \\
(0.1204)\end{array}$ & $\begin{array}{l}-0.0453 \\
(0.1201)\end{array}$ & $\begin{array}{l}-0.0451 \\
(0.1213)\end{array}$ & $\begin{array}{l}-0.0158 \\
(0.1278)\end{array}$ \\
\hline $\begin{array}{l}\text { Retail deposits } \\
\text { TLTRO }\end{array}$ & & & & $\begin{array}{l}0.0300 \\
(0.0315)\end{array}$ & $\begin{array}{l}0.0447 \\
(0.0363) \\
-0.0303 \\
(0.0460)\end{array}$ \\
\hline Observations & 498234 & 498234 & 498234 & 498234 & 498234 \\
\hline Bank controls & Yes & Yes & Yes & Yes & Yes \\
\hline Firm FE & Yes & Yes & Yes & Yes & Yes \\
\hline$R^{2}$ & 0.4009 & 0.4009 & 0.4010 & 0.4010 & 0.4010 \\
\hline
\end{tabular}




\section{Table A8: Baseline regressions-Negative Policy Rates and Bank Credit Supply, 1-month Window}

Notes: The table presents OLS estimates of model 1. The dependent variable is loan growth at the bank-firm-month level, calculated as $\log$ difference between the July 2014 (the post-NIRP period) and April 2014 (the pre-NIRP period). May and June 2014 are excluded from the sample. Net interbank position is measured by the ratio of interbank loans minus interbank deposits with maturity up to one week, over total assets, as of end-March 2014. Liquidity is the ratio of securities over total assets, as of March 2014. Retail deposits are measured as a share of total assets, as of March 2014. TLTRO is the ratio of total loans to euro area non-financial corporations and householdsexcluding loans to households for house purchase-over total assets, as of April 2014. Bank control variables include: i) Size, defined as the logarithm of total assets; ii) Capital, defined as the ratio of TIER 1 capital over total assets; and iii) NPL, defined as non-performing loans scaled by total assets. These three variables are measured as of March 2014. Standard errors, double clustered at the bank and firm level, are in parentheses. ${ }^{* * *} \mathrm{p}<0.01,{ }^{* *} \mathrm{p}<0.05,{ }^{*} \mathrm{p}<0.1$.

\begin{tabular}{|c|c|c|c|c|c|}
\hline & (1) & (2) & (3) & $(4)$ & (5) \\
\hline Window: & \multicolumn{5}{|c|}{ \pm 1 month around May-June 2014} \\
\hline Net interbank position & $\begin{array}{l}0.1083^{* *} \\
(0.0512)\end{array}$ & & $\begin{array}{l}0.0992^{*} \\
(0.0510)\end{array}$ & $\begin{array}{l}0.0987^{*} \\
(0.0523)\end{array}$ & $\begin{array}{l}0.0973^{*} \\
(0.0545)\end{array}$ \\
\hline Liquidity & & $\begin{array}{l}0.0356^{* * *} \\
(0.0112)\end{array}$ & $\begin{array}{l}0.0329^{* * *} \\
(0.0110)\end{array}$ & $\begin{array}{l}0.0343^{* *} \\
(0.0133)\end{array}$ & $\begin{array}{l}0.0323^{* *} \\
(0.0132)\end{array}$ \\
\hline Retail deposits & & & & $\begin{array}{l}0.0025 \\
(0.0145)\end{array}$ & $\begin{array}{l}0.0084 \\
(0.0206)\end{array}$ \\
\hline TLTRO & & & & & $\begin{array}{l}-0.0121 \\
(0.0245)\end{array}$ \\
\hline Observations & 487882 & 487882 & 487882 & 487882 & 487882 \\
\hline Firm FE & Yes & Yes & Yes & Yes & Yes \\
\hline$R^{2}$ & 0.3553 & 0.3553 & 0.3554 & 0.3554 & 0.3554 \\
\hline
\end{tabular}




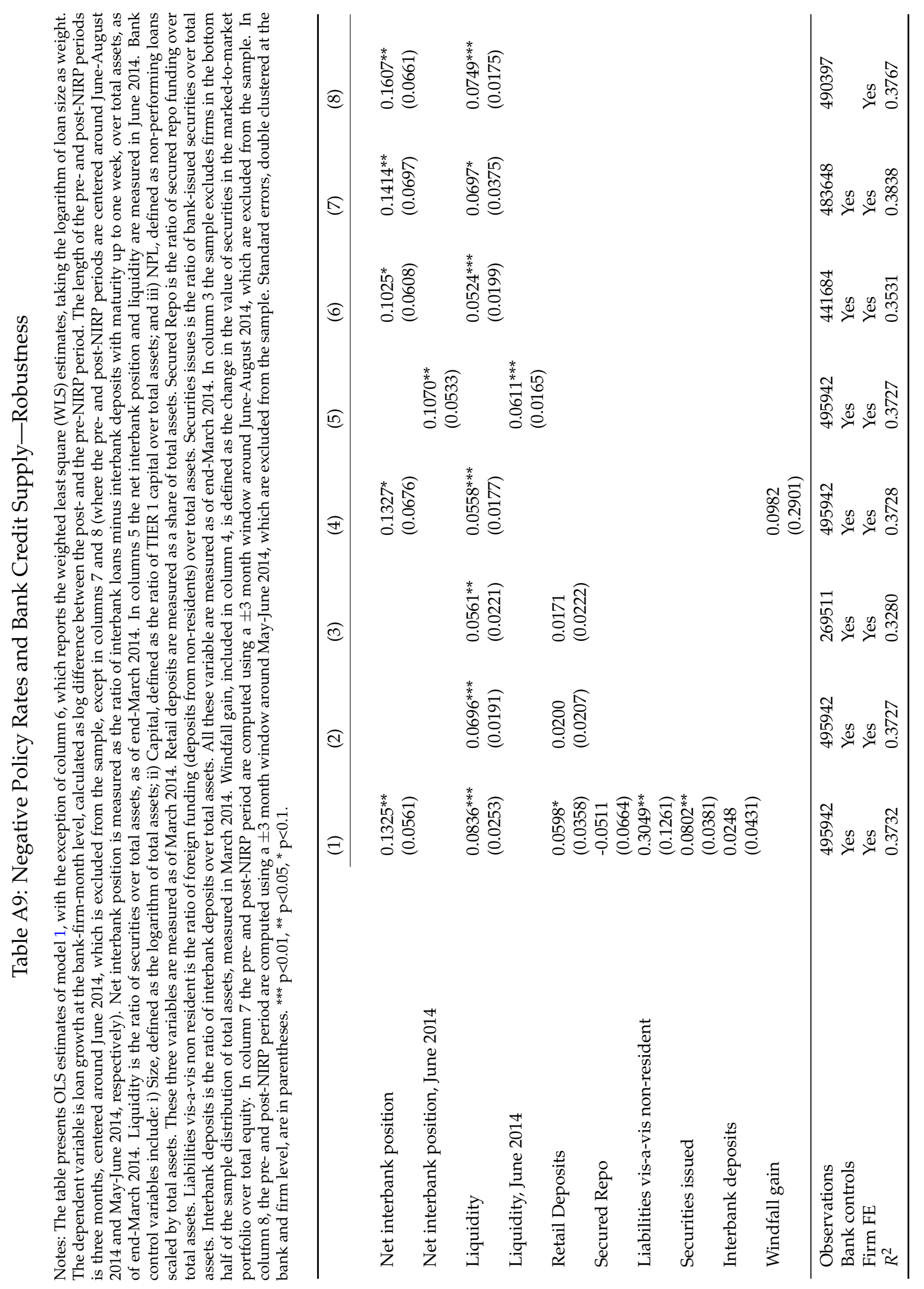




\section{Table A10: Negative Policy Rates, Net Interbank Position, and Liquidity, Placebos}

Notes: The table shows OLS estimates of a bank-level cross sectional regression. The dependent variables are: i) the change in the net interbank position (columns 1 and 3), and ii) the change in liquidity (columns 2 and 4 ) over the six months following two rate cuts episodes, one in July 2012 (columns 1-2) and the second in November 2013 (columns 3-4). The net interbank position is defined as the ratio of interbank loans minus interbank deposits with maturity up to one week, over total assets. Liquidity is defined as the ratio of securities over total assets. Bank control variables include: i) Size, defined as the logarithm of total assets; ii) Capital, defined as the ratio of TIER 1 capital over total assets; and iii) NPL, defined as non-performing loans scaled by total assets. Also the control variables are measured in the quarter before the rate cut. Robust standard errors in parentheses. ${ }^{* * *} \mathrm{p}<0.01,{ }^{* *} \mathrm{p}<0.05,{ }^{*} \mathrm{p}<0.1$.

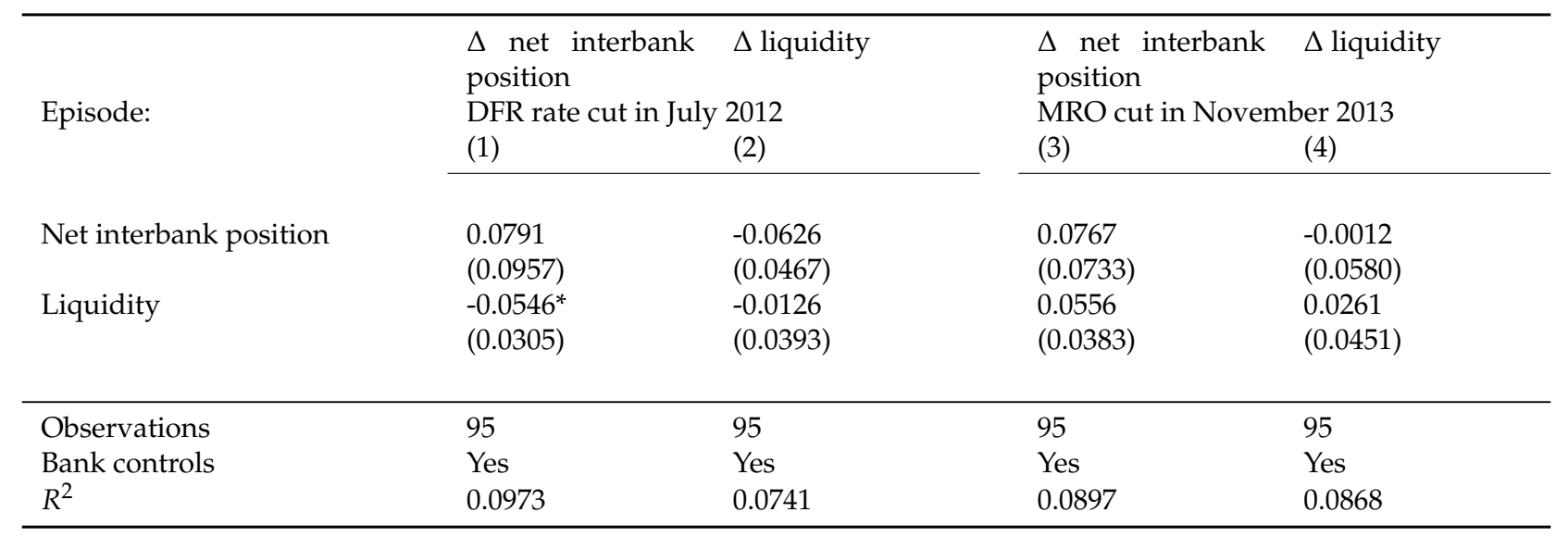




\section{Table A11: Negative Policy Rates and Bank Credit Supply_Parallel Trends}

Notes: The table presents OLS estimates of model 1. The dependent variable is loan growth at the bank-firm-month level, calculated as $\log$ difference between the post- and the pre- monetary policy announcement. In panel A, the length of the pre- and post-periods is three months, centered around: 1) December 2013 (column 1); 2) January 2014 (column 2); and February 2014 (column 3). We do not expand our sample beyond February 2014 as the \pm 3 months window around March 2014 will include June 2014 (and the introduction of NIRP) in the post-period. In panel B, the length of the pre- and post-periods is six months, centered around: 1) September 2013 (column 1); 2) October 2013 (column 2); and November 2013 (column 3). We do not expand our sample beyond November 2013 as the \pm 6 months window around December 2013 will include June 2014 (and the introduction of NIRP) in the post-period. In each model, the month of the policy announcement is excluded from the sample. Net interbank position in the interbank market is measured as the ratio of interbank loans minus interbank deposits with maturity up to one week, over total assets, as of end-March 2014. Liquidity is the ratio of securities over total assets as of March 2014. Bank control variables include: i) Size, defined as the logarithm of total assets; ii) Capital, defined as the ratio of TIER 1 capital over total assets; and iii) NPL, defined as non-performing loans scaled by total assets. These three variables are measured as of March 2014. Standard errors, double clustered at the bank and firm level, are in parentheses. ${ }^{* *} \mathrm{p}<0.01,{ }^{* *} \mathrm{p}<0.05,{ }^{*} \mathrm{p}<0.1$.

(1)

$(2)$

Panel A: \pm 3 months windows

\begin{tabular}{|c|c|c|}
\hline Sep 2013-Mar 2014 & Oct 2013-Apr 2014 & Nov 2013-May 2014 \\
\hline $\begin{array}{l}-0.0097 \\
(0.0467) \\
-0.0950^{* * *} \\
(0.0292)\end{array}$ & $\begin{array}{l}0.0072 \\
(0.0482) \\
-0.0678^{*} \\
(0.0367)\end{array}$ & $\begin{array}{l}0.0425 \\
(0.0479) \\
-0.0087 \\
(0.0252)\end{array}$ \\
\hline $\begin{array}{l}508784 \\
0.3787\end{array}$ & $\begin{array}{l}506734 \\
0.3778\end{array}$ & $\begin{array}{l}507318 \\
0.3762\end{array}$ \\
\hline
\end{tabular}

Panel B: \pm 6 months windows

\begin{tabular}{|c|c|c|c|}
\hline & Mar 2013-Mar 2014 & Apr 2013-Apr 2014 & May 2013-May 2014 \\
\hline $\begin{array}{l}\text { Net interbank position } \\
\text { Liquidity }\end{array}$ & $\begin{array}{l}0.0104 \\
(0.0740) \\
-0.0125 \\
(0.0221)\end{array}$ & $\begin{array}{l}0.0035 \\
(0.0681) \\
-0.0351 \\
(0.0237)\end{array}$ & $\begin{array}{l}0.0296 \\
(0.0665) \\
-0.0530^{*} \\
(0.0279)\end{array}$ \\
\hline $\begin{array}{l}\text { Observations } \\
\text { Firm FE } \\
\text { Bank controls } \\
R^{2}\end{array}$ & $\begin{array}{l}522720 \\
\text { Yes } \\
\text { Yes } \\
0.4061\end{array}$ & $\begin{array}{l}518876 \\
\text { Yes } \\
\text { Yes } \\
0.4062\end{array}$ & $\begin{array}{l}514457 \\
\text { Yes } \\
\text { Yes } \\
0.4061\end{array}$ \\
\hline
\end{tabular}

The negative coefficients of liquidity in some specifications can be explained by the fact that, as discussed in Section 4.3, in November 2013 the ECB lowered the interest rate on the MRO without flattening the yield curve (see Figure 4, panel b). 


\section{Table A12: Negative Policy Rates and Non-Performing Loans}

Notes: The table shows OLS estimates of a bank-level cross sectional regression. The dependent variable is the change in banks' nonperforming loans (NPL) scaled by total assets over: (i) the 12 months period following the introduction of NIRP, March 2014-March 2015 (top panel), and (ii) the 60 months period following the introduction of NIRP, March 2014-March 2019 (bottom panel). Net interbank position is measured as the ratio of interbank loans minus interbank deposits with maturity up to one week, over total assets, as of endMarch 2014. Liquidity is the ratio of securities over total assets, as of March 2014. Bank control variables include: i) Size, defined as the logarithm of total assets; ii) Capital, defined as the ratio of TIER 1 capital over total assets; and iii) NPL, defined as non-performing loans scaled by total assets. These three variables are measured as of March 2014. Data on the change in banks' non-performing loans is missing for 1 bank in our baseline sample, as the bank is not operative in March 2015. Robust standard errors in parentheses. ${ }^{* *} \mathrm{p}<0.01,{ }^{* *} \mathrm{p}<0.05$, ${ }^{*} \mathrm{p}<0.1$.

(1)

Period: March 2014 - March 2015

\begin{tabular}{llll}
\hline Net interbank position & -0.0150 & & -0.0101 \\
& $(0.0119)$ & $0.0242)$ \\
Liquidity & & 0.0127 & 0.0102 \\
& & $(0.0107)$ & $(0.0138)$ \\
\hline Observations & 94 & 94 & 94 \\
$R^{2}$ & 0.4027 & 0.4046 & 0.4067 \\
\hline
\end{tabular}

Period: March 2014 - March 2019

\begin{tabular}{llll}
\hline Net interbank position & -0.0170 & & -0.0020 \\
Liquidity & $(0.0430)$ & $0.0442)$ \\
& & 0.0313 & 0.0307 \\
& & $(0.0314)$ & $(0.0319)$ \\
\hline Observations & 91 & 91 & 91 \\
Bank controls & Yes & Yes & Yes \\
$R^{2}$ & 0.3759 & 0.3804 & 0.3804 \\
\hline
\end{tabular}




\section{Table A13: Negative Policy Rates and Gross Lending Rates}

Notes: The table presents OLS estimates of model 1. The dependent variable is the change in gross lending rates, which include commissions and fees, at the bank-firm-month level, calculated as difference between the post- and the pre-NIRP period. The length of the preand post-NIRP period is of six months, centered around June 2014, which is excluded from the sample. Panel A reports the results for the change in gross lending rates on credit lines and overdraft facilities, while Panel B reports the results for term loans. Net interbank position is measured as the ratio of interbank loans minus interbank deposits with maturity up to one week, over total assets, as of end-March 2014. Liquidity is the ratio of securities over total assets as of March 2014. Retail deposits are measured as a share of total assets, as of March 2014. TLTRO is the ratio of total loans to euro area non-financial corporations and households-excluding loans to households for house purchase-over total assets, as of April 2014. Bank control variables include: i) Size, defined as the logarithm of total assets; ii) Capital, defined as the ratio of TIER 1 capital over total assets; and iii) NPL, defined as non-performing loans scaled by total assets. These three variables are measured as of March 2014. Standard errors, double clustered at the bank and firm level, are in parentheses. ${ }^{* * *} \mathrm{p}<0.01,{ }^{* *}$ $\mathrm{p}<0.05,{ }^{*} \mathrm{p}<0.1$

\begin{tabular}{|c|c|c|c|c|}
\hline & \multicolumn{4}{|c|}{ Panel A: Credit lines and overdraft facilities, net rates } \\
\hline $\begin{array}{l}\text { Net interbank position } \\
\text { Liquidity } \\
\text { Retail Deposits }\end{array}$ & $\begin{array}{l}-0.1005^{* * *} \\
(0.0282)\end{array}$ & $\begin{array}{l}-0.0478^{* * *} \\
(0.0136)\end{array}$ & $\begin{array}{l}-0.0819^{* * *} \\
(0.0157) \\
-0.0449^{* * *} \\
(0.0122)\end{array}$ & 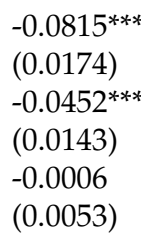 \\
\hline $\begin{array}{l}\text { Observations } \\
\text { Firm FE } \\
R^{2}\end{array}$ & $\begin{array}{l}188690 \\
\text { Yes } \\
0.3959\end{array}$ & $\begin{array}{l}188690 \\
\text { Yes } \\
0.3974\end{array}$ & $\begin{array}{l}188690 \\
\text { Yes } \\
0.3979\end{array}$ & $\begin{array}{l}188690 \\
\text { Yes } \\
0.3979\end{array}$ \\
\hline$R^{2}$ & \multicolumn{4}{|c|}{ Panel B: Term loans, net rates } \\
\hline $\begin{array}{l}\text { Net interbank position } \\
\text { Liquidity } \\
\text { Retail Deposits }\end{array}$ & $\begin{array}{l}-0.0063^{* *} \\
(0.0030)\end{array}$ & $\begin{array}{l}-0.0042^{* *} \\
(0.0017)\end{array}$ & $\begin{array}{l}-0.0047^{*} \\
(0.0025) \\
-0.0040^{* *} \\
(0.0016)\end{array}$ & $\begin{array}{l}-0.0051^{*} \\
(0.0026) \\
-0.0037^{*} \\
(0.0020) \\
0.0005 \\
(0.0012)\end{array}$ \\
\hline $\begin{array}{l}\text { Observations } \\
\text { Firm FE } \\
R^{2}\end{array}$ & $\begin{array}{l}113842 \\
\text { Yes } \\
0.4094\end{array}$ & $\begin{array}{l}113842 \\
\text { Yes } \\
0.4102\end{array}$ & $\begin{array}{l}113842 \\
\text { Yes } \\
0.4103\end{array}$ & $\begin{array}{l}113842 \\
\text { Yes } \\
0.4103\end{array}$ \\
\hline
\end{tabular}




\section{A.3 U.S. QE: Evidence from Survey Data}

We complement the evidence on U.S. QE episodes discussed in Section 4.6 with an analysis of microdata from the quarterly Senior Loan Officer Opinion Surveys (SLOOS) conducted by the Federal Reserve. The purpose of the survey is to gather qualitative and quantitative information about bank credit availability and loan demand, as well as on lending practices in the U.S. bank loan market. ${ }^{43}$ We use the confidential bank-level responses to test if the probability with which banks report tightening C\&I lending standards is relatively lower for more liquid banks in the two quarters after each QE announcement. These data have the benefit that we can control for concurrent shifts in loan demand directly using banks' own assessment of how loan demand changes each quarter. The smallest participating bank in the SLOOS has total assets of about $\$ 2$ billion and 75-80 banks participate in each survey round.

The dependent variable is a dummy variable taking value one for banks that reported that they tightened lending standards "somewhat" or "considerably" in response to the question "Over the past three months, how have your bank's credit standards for approving applications for CEI loans or credit lines-other than those to be used to finance mergers and acquisitions — to large and middle-market firms and to small firms changed?" (and zero otherwise). Since the banks give separate responses for large versus small firms (with less than USD 50 million in annual sales), we stack the responses across the two size groups and across all surveys to obtain a panel at the bank-survey-borrower size level (where borrower size is either large or small firms). Then we regress the dependent variable on the key variable of interest—bank liquidity—and other balance sheet controls, including a dummy variable that takes value one for banks reporting stronger loan demand over the quarter (and zero otherwise). For each event, we study changes in lending standards in the two quarters before and after the QE announcement. Bank balance sheet variables are measured at quarter-end before the announcement.

As shown in Table A14, the results support the idea of a portfolio rebalancing channel. Banks with more liquid assets before $\mathrm{QE}$ are relatively less likely to tighten C\&I lending standards after each QE event. The coefficient estimates are positive and significant across all specifications. Notwithstanding that these results are based on banks' self-assessments of changes in lending standards and loan demand, and on a sample skewed toward larger banks, we believe they are nevertheless suggestive of our channel. ${ }^{44}$

\footnotetext{
${ }^{43}$ For more information, see https: / www.federalreserve.gov/data/sloos/about.htm.

${ }^{44}$ In results not reported, we examine the QE3 event in September 2012, which was not followed by a flattening of the yield curve (Figure 5, panel C), as a placebo test. We find no systematic relation between ex ante bank liquidity and the probability of changing credit standards after that announcement.
} 


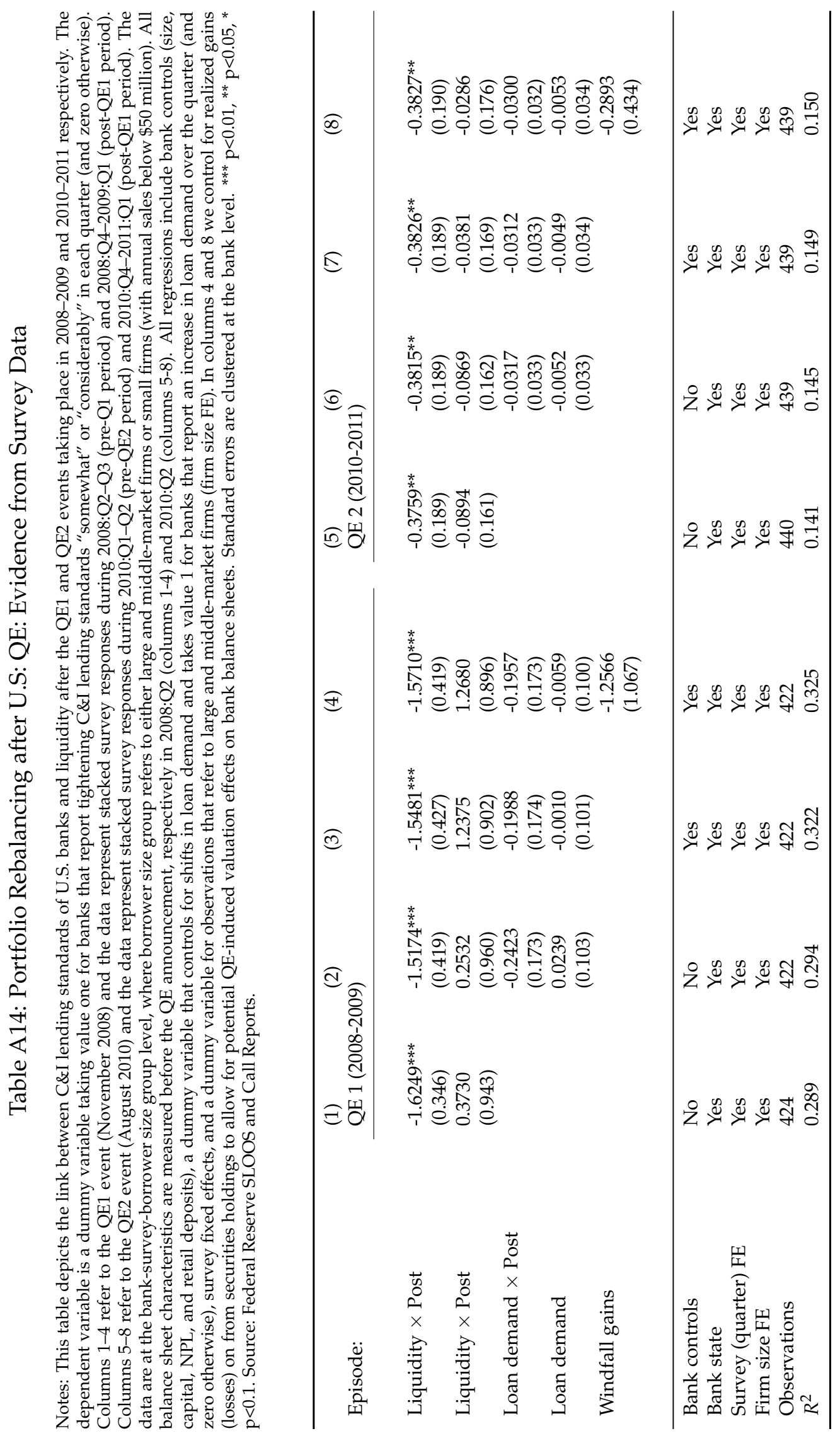

